\title{
DAYA SAING INDUSTRI KACANG GOYANG DI KOTAMOBAGU (STUDI KASUS DI USAHA DAGANG BERUSAHA DAN USAHA DAGANG KABELA)
}

\author{
Windy Amelia Makakombo \\ Leonardus R. Rengkung \\ Celcius Talumingan
}

\begin{abstract}
The purpose of this study is to analyze the Competitivences of 'Kacang Goyang' industry of 'UD Berusaha' and 'UD Kabela' Kotamobagu, North Sulawesi. This study was conducted over three months from July to October 2015 in Motoboi Kecil, South Kotamobagu, North Sulawesi. Data used in this study are primary and secondary data. Primary data collection is done by interview using questionnaires and secondary data derived from Dinas Pertanian. The used analysis is Importance Performance Analysis (IPA). The result showed that consumers are satisfied with the level of the cleanliness, appearance and performance. Prices offered by the two businesses are affordable and is according to the contents of products and flavors. The consumen is satisfied with the price. Consumers' considended that the two companies have a clean and comfortable place, but there are some aspects that should be corrected such as, location and parking. Consumers also considened that this two companies provide a good service in the aspect of speed, knowledge and friendliness, but consumers have not been satisfied in the physical aspect, dressed, and neatness. *lrr*
\end{abstract}

Keywords: the Competitivences of industry, Importance Performance Analysis, Kotamobagu

\section{ABSTRAK}

Penelitian ini bertujuan untuk menganalisis daya saing industri kacang goyang Usaha Dagang (UD) Berusaha dan UD. Kabela Kota Kotamobagu, Sulawesi Utara. Penelitian ini dilakukan selama empat bulan dari bulan Juli sampai November 2015. Tempat penelitian adalah di Kelurahan Motoboi Kecil Kecamatan Kotamobagu Selatan Kota Kotamobagu Provinsi Sulawesi Utara. Data yang di peroleh dalam penelitian ini meliputi data primer dan sekunder. Pengumpulan data primer dilaksanakan dengan teknik wawancara yang mengunakan kusioner sedangkan data sekunder diambil dari instansi-instansi yang terkait langsung dengan penelitian seperti Dinas Pertanian. Penelitian ini menggunakan analisis Importance Performance Analysis (IPA). Hasil penelitian menunjukkan puas terhadap pembeli baik dari segi kebersihan, tampilan, dan bentuk dari penyajian kacang goyang tersebut. Aspek harga yang ditawarkan oleh UD. Berusaha dan UD. Kabela menunjukkan bahwa harga yang ditawarkan terjangkau. Harga sesuai isi produk dan cita rasa. Pembeli merasa puas dengan harga yang ditetapkan. Aspek Tempat yang digunakan UD. Berusaha dan UD. Kabela baik dari tingkat kebersihan dan kenyamanan sudah sangat memuaskan pembeli, hanya ada beberapa aspek yang perlu dibenahi oleh pabrik demi meningkatkan kepuasan pembeli yaitu ketersediaan tempat parkir yang luas serta lokasi pemasaran yang belum strategis. Aspek Pelayanan yang diberikan oleh karyawan UD. Berusaha dan UD. Kabela baik itu dari kecepatan, kesigapan, pengetahuan, dan keramahan sudah sangat memuaskan pembeli, hanya penampilan fisik dari karyawan tersebut baik dari berpakaian dan kerapihan yang ditunjukan belum memuaskan pembeli.

Kata Kunci Daya saing industri, Analisa Kepuasan dan Kepentingan, Kotamobagu

\section{PENDAHULUAN}

\section{Latar Belakang}

Sektor pertanian mempunyai peranan penting dalam perkembangan kemajuan ekonomi suatu negara, baik bagi negara maju maupun negara yang sedang berkembang, karena sektor pertanian ini memiliki kontribusi bagi suatu negara.
Indonesia sebagai negara kepulauan yang kaya akan sumber daya alam, jika ditinjau dari sumber daya penduduk Indonesia, penduduk Indonesia hidup dan bekerja di sektor pertanian, baik yang berada di daerah pedesaan maupun di perkotaan, dalam hal ini sektor pertanian masih memegang peranan penting dalam perekonomian Indonesia. 
Di Sulawesi Utara banyak hasil pertanian yang mempunyai nilai dan berdaya saing tinggi salah satu hasil pertaniannya yaitu kacang tanah. Kacang tanah merupakan tanaman pangan yang dibutuhkan manusia dengan mutu yang layak, aman dikonsumsi, dan harga yang terjangkau disetiap saat. Sejak awal Pelita I, strategi perekonomian Indonesia difokuskan pada sektor pertanian. Strategi ini ditempuh karena kacang tanah sebagai salah satu bahan pangan yang strategis dan memainkan peranan penting dalam perekonomian Indonesia.

Salah satu produk agroindustri yang dikelolah adalah kacang goyang. Di Kotamobagu tepatnya di Daerah Motoboi Kecil terdapat beberapa industri kacang goyang yaitu industri UD.Beusaha dan UD. Kabela. Karena itu Kotamobagu (Kota Kotamobagu) menjadi sentra produksi kuliner khas Sulawesi Utara (Sulut) yang selalu laris manis.

Usaha kacang goyang yang dirintis sejak 1970-an itu merupakan usaha keluarga, selain itu juga dikelolah melalui usaha lintas keluarga secara turun temurun. Selain di Sulut kacang goyang juga sudah dipasarkan di beberapa daerah, yakni dipasar Irian Jaya, Kalimantan dan beberapa daerah lain. Masyarakat Kota Kotamobagu juga dapat berbangga karena produk asli Totabuan ini bisa menembus pasar dunia, seperti di Singapur (Manado Post, 2011).

Dalam hal ini pemasaran kacang goyang buatan Kotamobagu terus berupaya untuk mempertahankan perannya dipasar sehingga tetap menjaga posisinya dalam persaingan. Untuk mengetahui kacang goyang yang berasal dari Kotamobagu relatif mudah yaitu dengan melihat warna gula yang membalut kacang, ada putih, coklat, dan merah muda. Bila dalam satu kemasan kacang goyang, warnanya coklat dan putih atau merah muda maka itu berasal dari Kotamobagu.

Kacang goyang buatan Kotamobagu terdapat persaingan dalam pemasaran. Persaingan yang ada tidak hanya antar merek tetapi juga terdapat persaingan antar industri. Persaingan antar industri terjadi antar industri kacang goyang Amurang dan kacang goyang Kotamobagu. Sedangkan persaingan antar merek yaitu kacang goyang UD. Berusaha yang sudah berproduksi selama 32 tahun, kacang goyang UD. Kabela yang sudah berproduksi selama 19 tahun.

Industri kacang goyang bersaing disamping rasa, kualitas dan juga harga. Namun diindustri yang ada di Kotamobagu selain memproduksi kacang goyang mereka juga memproduksi nogat dan kacang telur sebagai tambahan.

Situasi persaingan yang begitu tinggi saat ini telah memaksa suatu industri untuk lebih meningkatkan daya saingnya hingga mencapai tingkatan superior competitive advantage diantara pesaing-pesaingnya. Hal lainnya, suatu industri dituntut untuk terus meningkatkan kapasitas dalam usaha memuaskan kebutuhan konsumennya (Hubeis, 2002).

Setiap industri selalu berupaya untuk tetap eksis serta untuk selalu ingin tumbuh dan berkembang. Oleh karena itu suatu industri akan selalu berupaya untuk dapat mempertahankan berkesinambungannya masa hidup nilai pelanggan yang diberikan. Industri akan mampu menghasilkan dan mendapatkan laba secara berkesinambungan, apabila industri menjalankan konsep pemasaran yang menekan upayanya pada pelayanan pelanggan yang harus lebih daripada yang dilakukan para pesaingnya. Dalam upaya untuk mencapai tujuan industri itu, maka perlu diketahui bagaimana nilai pelanggan diciptakan oleh suatu industri dan bagaimana nilai pelanggan yang baik dapat memberikan kepuasan kepada pelanggan. Perlu dipahami bahwa kepuasan pelanggan yang berkelanjutan atau berkesinambungan dicapai melalui nilai pelanggan yang dapat terus dijaga atau ditingkatkan. Dengan upaya tersebut diharapkan loyalitas pelanggan dapat ditingkatkan dan peningkatan loyalitas pelanggan yang berkelanjutan dapat dibina melalui rencana keputusan strategi, yang dikenal dengan pemasaran strategi. Pasar dimanapun berada akan selalu tetap berubah, tetapi kegiatan aktivitas pemasaran tidaklah berubah secepat perubahan pasar. Perubahan pasar disebabkan oleh perubahan kondisi permintaan dan persaingan. Dengan terdapatnya kondisi perubahan tersebut, maka strategi pemasaran yang berbeda dalam kondisi persaingan tertentu, kemungkinan akan dapat berhasil mencapai sasaran. 
Keberhasilan dari pelaksanaan kegiatan pemasaran produk suatu industri, umumnya terletak pada keberhasilan industri itu dalam memenuhi pelayanan atas kebutuhan dan keinginan pelanggan untuk suatu produk sesuai harapan, sehingga dapat meningkatkan pertumbuhan penjualan dan keuntungan dari pelanggan loyal. Dengan demikian yang paling stratejik dalam pemasaran yang dilakukan oleh suatu industri atas produknya adalah pasar yang dibidik dan menjadi pasar sasaran, yaitu pelanggan loyal.

Dalam pencapaian tujuan dan sasaran industri, khususnya dibidang pemasaran haruslah ditentukan tempat arena bermainnya dalam pasar persaingan, untuk itu harus dipertimbangkan segmen pasar yang ada dan dari segmen-segmen tersebut ditetapkan pasar sasaran.

Dengan penetapan pasar sasaran, dimana suatu industri atau unit bisnis memfokuskan aktivitas usahanya, terutama aktivitas pemasaran, maka industri itu menjalankan kegiatan pemasaran secara terkait, terpadu dan dalam rangka satu kesatuan pemasaran industri. Dilakukan dengan satu arahan atau panduan dalam bentuk keputusan-keputusan stratejik, yang dikenal dengan rencana pemasaran stratejik. Didalam panduan rencana stratejik maka ditetapkanlah upaya-upaya pemposisian yang dijalankan didalam satu pasar sasaran (Assauri 2012).

Upaya pemasaran dalam bisnis industri yang dipusatkan pada kebutuhan pelanggan, pada akhirnya dapat membentuk kepuasan pelanggannya. Kuat tidaknya fokus pelanggan bisnis industri sangat tergantung pada bagaimana baiknya pemahaman industri atas pesaing-pesaing kuncinya serta kekuatan kompetitifnya. Persaingannya juga akan terus berubah karena perkembangan dan terdapatnya kemajuan teknologi baru.

\section{Deskripsi Umum Tanaman Kacang Tanah}

Kacang tanah merupakan tanaman pangan berupa semak yang berasal dari Amerika Selatan diperkirakan dari lereng pegunungan Andes. Penanaman dilakukan pertama kali oleh orang indian. Kacang tanah ini pertama kali masuk di Indonesia pada abad ke 17 dibawa oleh pedagang Cina dan Portugis.

Dilihat dari sifatnya, kacang tanah tumbuh diwilayah tropis, subtropics, dan Negara yang beriklim sedang. Kacang tanah merupakan tanaman yang sangat penting di daerah Afrika, Asia, Amerika Utara and Amerika Selatan. Di Asia, kacang tanah merupakan tanaman budidaya utama di negara India, Cina, Indonesia, Burma, Thailand dan Vietnam.

Bagi masyarakat Indonesia, kacang tanah memiliki nama atau sebutan yang berbeda-beda seperti kacang Una, kacang Suuk, kacang Jebrol, kacang Bandung, kacang Tuban. Sedangkan dalam bahasa Inggris, kacang tanah biasa disebut peanut atau groundnut. Dan dalam bahasa latinnya kacang tanah disebut Arachis hypogaea.

Dalam pengertiannya, kacang adalah istilah non-botani yang biasa dipakai untuk menyebut biji dari sejumlah tumbuhan keluarga polong-polongan, meski tidak semuanya disebut kacang. Kacang tanah bagi masyarakat Indonesia merupakan sumber protein nabati kedua terbesar setelah kedelai. Namun, produksi kacang tanah di Indonesia belum optimal karena teknik produksi yang belum memadai dan minimnya penggunaan benih unggul. Dampaknya kebutuhan dalam negeri yang meningkat tidak bisa dipenuhi sehingga volume impor kacang menjadi tinggi.

$\underline{\text { Klasifikasi Kacang Tanah }}$

Kerajaan : Plantae

Divisi : Tracheophyta

Kelas : Magnoliophyta

Ordo : Leguminales

Family : Papilionaceace

Genus : Arachis

Spesies : Arachis zhypogeae L.

Teknik bercocok tanam yang baik sangat diperlukan untuk mendapatkan hasil yang sesuai dengan harapan. Hal ini harus di mulai dari awal, yaitu sejak dilakukan pembibitan sampai tanaman itu bisa dipanen. Dalam proses pertumbuhan tanaman hingga berbuah ini diperlukan pemeliharaan yang baik, terutama harus diusahakan agar tanaman terhindar dari 
serangan hama dan penyakit yang sering kali menurunkan produksi (AAK, 1990).

Usaha kacang tanah meliputi berbagai kegiatan pekerjaan antara lain:

\section{1) Persyaratan Benih}

Syarat benih/bibit yang baik adalah berasal dari tanaman yang baru dan varietas unggul, kulit benih mengkilap, tidak keriput dan cacat, murni tidak tercampur dengan varietas lain, kadar air benih berkisar $9-12 \%$

\section{2) Penyiapan Benih}

Benih sebaiknya disimpan ditempat kering yang konstan dan tertutup rapat. Untuk menjamin kualitas benih.

\section{3) Persiapan dan pembukaan lahan}

Pembukaan lahan dengan pembajakan dan pencangkulan untuk pembersihan lahan dari segala macam gulma dan akar-akar tanaman sebelumnya.

\section{4) Pembentukan bendengan}

Buat bedengan ukuran lebar $80 \mathrm{~cm}$, panjang menyesuaikan, ketebalan bedengan $20-30 \mathrm{~cm}$, diantara bedengan dibuatkan parit.

\section{5) Cara penanaman}

Masukkan benih 1 atau 2 butir ke dalam lubang tanam dengan tanah tipis, waktu tanam yang baik dilahan kering pada awal musim hujan

\section{6) Pemeliharaan tanaman}

Sulam benih yang tidak tumbuh atau mati, untuk penyulaman lebih cepat lebih baik. Penyiangan dilakukan 2 kali, umur 1 dan 6 minggu dengan hati-hati agar tidak merusak bunga dan polong. Pengairan dan penyiraman dilakukan agar tanah tetap lembab, untuk menjaga kelembaban pada musim kemarau diberikan mulsa. Saat berbunga tidak dilakukan penyiraman karena dapat menggangu pe-nyerbukan.

\section{7) Hama dan Penyakit}

Hama yang menyerang tanaman yaitu uret, ulat, kumbang daun, sedangkan penyakit yaitu layu, bercak daun, karat, sclerotium.

\section{8) Panen}

Umur panen tanaman kacang tanah tergantung dari jenisnya yaitu umur pendek 3-4 bulan dan umur panjang 5-6 bulan. Adapun ciriciri kacang tanah yang sudah siap dipanen antara lain :

a. Batang mulai mengeras.

b. Daun menguning dan sebagian mulai berguguran

c. Warna polong coklat kehitam-hitaman.

Dari kegitan usahatani kacang tanah diperlukan biaya. Dan biaya-biaya tersebut adalah sewa tanah, alat pertanian yang merupakan biaya tetap, dan untuk biaya variabel antara lain biaya untuk sarana produksi misalnya tenaga kerja, pupuk dan sebagainya.

\section{Konsep Daya saing}

Sebagian pakar mengungkapkan bahwa konsep daya saing (Competitivness) berpijak dari konsep keunggulan komparatif (Comparative advantage). Namun, sebagian pakar lain mengemukakan bahwa konsep daya saing (Competitivnes) atau keunggulan kompetitif (Comparative advantage) bukan merupakan konsep ekonomi, melainkan konsep politik bahkan konsep bisnis yang digunakan sebagai dasar banyak analisis strategis untuk meningkatkan kinerja perusahaan.

Menurut Simatupang (1991) serta Sudaryanto dan Simatupang (1993) konsep ukuran komparatif merupakan ukuran daya saing (keunggulan) potensial dalam hal daya saing akan dicapai apabila perekonomian tidak mengalami distorsi sama sekali. Komoditas yang memiliki keunggulan komparatif dikatakan juga memiliki efisiensi secara ekonomi. Keunggulan kompetitif (Revealed competitive advantage / RCA) merupakan pengukur daya saing suatu kegiatan pada kondisi perekonomian aktual. Terkait dengan konsep keunggulan komparatif adalah kelayakan ekonomi, sedangkan terkait dengan keunggulan kompetitif adalah kelayakan finansial dari suatu aktifitas. Sumber distorsi yang dapat menganggu tingkat daya saing antara lain adalah (a) kebijakan pemerintah (government policy), baik yang bersifat langsung (seperti tarif) maupun tidak langsung (seperti regulasi) dan (b) distorsi pasar, karena adanya ketidaksempurnaan pasar (market 
imperfection), misalnya adanya monopoli/ monopsoni domestic.

Dapat terjadi bahwa ditingkat produsen suatu komoditi memiliki keunggulan komparatif, memiliki biaya oporturnitas (oppurtunity cost) yang relatif rendah, namun ditingkat konsumen ia tidak memiliki daya saing (keunggulan kompetitif) karena adanya distorsi pasar dan atau/biaya transaksi yang tinggi. Hal- hal sebaliknya juga dapat terjadi: karena adanya dukungan (campur tangan) kebijakan pemerintah, suatu komoditi memiliki daya saing ditingkat konsumen padahal ia tidak memiliki keunggulan komparatif di tingkat produsen.

Esterhuizen et. al. (2008) mendefinisikan daya saing (Competitivness) "as the ability a sector, industri of firm to compete sucscesffuly in order to achieve sustainable growth within the global environment while earning at last the opportunity cost of return on resources employed". Daya saing didefinisikan sebagai kemampuan suatu sektor, industri, atau suatu perusahan untuk bersaing dengan sukses untuk mencapai pertumbuhan yang berkelanjutan dalam lingkungan global selama biaya imbangnya lebih rendah dari penerimaan sumber daya yang digunakan.

Michael Porter, Profesor Ilmu Ekonomi dan ahli manjemen strategi dari Harvard University (1990; 1998), melakukan studi kasus yang sukses di sepuluh negara maju atau negara industri (Jerman, Itali, Jepang, Singapura, Korea Selatan, Swiss, Inggris, Denmark, USA, dan Zwitzerland) dengan melakukan studi pada 100 perusahaan. Porter mengemukakan bahwa :" we need perspective and new tools-an approach to competitivnes that grows directly out of an analysis of internationally successful industries, without regard to traditional idieology or current intellectual fashion". We need to know, very simple, what work and why". Secara ringkas Porter mendefinisikan daya saing (Competitiviness) sebagai suatu kemampuan Negara untuk menciptakan nilai tambah yang berkelanjutan melalui kegiatan perusahan perusahannya dan untuk mempertahankan tingkat kualitas kehidupan yang tinggi bagi warga negaranya.

Porter berusaha untuk mengkaji daya saing (Competitiviness) dari perspektif mikro (perusahaan) ke perspektif daya saing bangsa/negara (National Competitive Advantage), yang bukunya dipublikasikan dengan judul "The Competitive Advantege of Nations". Intinya adalah pentingnya inovasi dibidang ilmu pengetahuan dan teknologi. Konsep Porter dikenal sebagai Diamond of Advantage:

(1). Conditions factor, yaitu posisi Negara dalam hal penguasaan faktor produksi, seperti tenaga kerja terampil atau infrakstruktur, merupakan syarat kecukupan untuk bersaing. (2). Demand conditions, secara alamiah besarnya permintaan pasar domestik (home market) untuk produk-produk dan jasa-jasa industri.

(3). Relating and supporting industries, kehadiran industri pemasok (pendukung) dan lain-lain dalam suatu Negara dapat berkaitan dengan kemampuan daya saing industriindustri di pasar internasional.

(4). Firms strategy, structure and rivalry, kondisi pemerintah didalam suatu Negara bagaimana perusahan-perusahan diciptakan, diorganisasi dan dikelolah sebaik persaingan domestik secara ilmiah.

\section{Analisis Data}

Analisis data yang digunakan dalam penelitian ini adalah IPA (Importance Performance Analysis). Rumus yang digunakan dalam IPA adalah sebagai berikut: Rumus yang digunakan dalam IPA adalah sebagai berikut :

$$
T R i=\frac{X_{i}}{Y_{i}} \times 100 \%
$$

Keterangan :

$\mathrm{TK}_{\mathrm{i}}=$ Tingkat kesesuaian responden

$\mathrm{Xi}=$ Skor penilaian tingkat kinerja/kepuasan

$\mathrm{Yi}=$ Skor penilaian kepentingan 
Metode IPA pertama kali diperkenalkan oleh Martilla dan James (1997) dengan tujuan untuk mengukur hubungan antara persepsi konsumen dan prioritas peningkatan kualitas/ produk/jasa yang dikenal pula sebagai quadrant analysis (Brandt, 2000 dan Latu \& Everrt, 2000). IPA mempunyai fungsi utama untuk menampilkan informasi berkaitan dengan faktor-faktor pelayanan yang menurut konsumen perlu ditingkatkan karena kondisi saat ini belum memuaskan. Importance Performance Analysis (IPA) secara konsep merupakan suatu model multi-atribut. Teknik ini mengidentifikasi kekuatan dan kelemahan penawaran pasar dengan menggunakan dua kriteria yaitu kepentingan relatif atribut dan kepuasan konsumen.

Penerapan teknik IPA dimulai dengan identifikasi atribut-atribut yang relevan terhadap situasi pilihan yang diamati. Daftar atribut-atribut dapat dikembangkan dengan mengacu kepada literatur-literatur, melakukan interview, dan menggunakan penilaian manajerial. Di lain pihak, sekumpulan atribut yang melekat kepada barang atau jasa dievaluasi berdasarkan seberapa penting masing-masing produk tersebut bagi konsumen dan bagaimana jasa atau barang tersebut dipersepsikan oleh konsumen. Evaluasi ini biasanya dipenuhi dengan melakukan survei terhadap sampel yang terdiri atas konsumen. Setelah menentukan atribut-atribut yang layak, konsumen ditanya dengan dua pertanyaan Satu adalah atribut yang menonjol dan yang kedua adalah kinerja perusahaan yang menggunakan atribut tersebut. Dengan menggunakan mean, median atau pengukuran ranking, skor kepentingan dan kinerja atribut dikumpulkan dan klasifikasikan ke dalam kategori tinggi atau rendah; kemudian dengan memasangkan kedua set rangking tersebut, masing-masing atribut ditempatkan ke dalam salah satu dari empat kuadran kepentingan kinerja (Crompton dan Duray, 1985). Skor mean kinerja dan kepentingan digunakan sebagai koordinat untuk memplotkan atributatribut individu pada matriks dua dimensi yang ditunjukkan pada Gambar 1.
Gambar 1. Matriks Kinerja dan Kepentingan

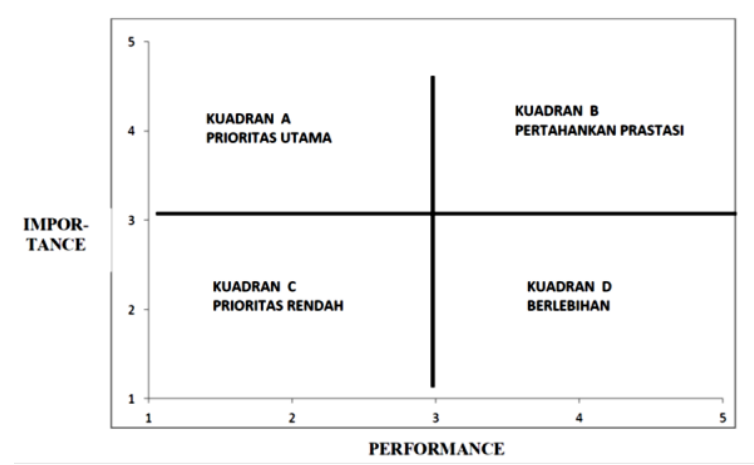

Keterangan Gambar 1:

- Menunjukkan faktor atau atribut yang dianggap mempengaruhi pelanggan, termasuk unsurunsur jasa yang dianggap sangat penting, namun produk tidak sesuai keinginan pelanggan sehingga tidak puas.

- Menunjukkan unsur pokok yang sudah ada pada produk sehingga wajib dipertahankan serta dianggap sangat penting dan memuaskan.

- Menunjukkan faktor yang kurang penting pengaruhnya bagi pelanggan, keberadaannya biasa-biasa saja dan dianggap kurang penting serta kurang memuaskan.

- Menunjukkan faktor yang mempengaruhi pelanggan kurang penting namun pelaksanaannya berlebihan, dianggap kurang penting tetapi sangat memuaskan.

Matriks pada Gambar 1 digunakan untuk menggambarkan prioritas atribut-atribut guna perbaikan ke depan (Slack, 1991) dan dapat memberikan panduan untuk formulasi strategi (Burns, 1986).

Adapun contoh Skor Nilai Kepentingan dan Kepuasan yang digunakan adalah sebagai berikut:

Tabel 1. Skor Tingkat Kepentingan dan Kepuasan

\begin{tabular}{cll}
\hline $\begin{array}{c}\text { Skor/ } \\
\text { Nilai }\end{array}$ & \multicolumn{1}{c}{$\begin{array}{c}\text { Tingkat } \\
\text { Kepentingan }\end{array}$} & $\begin{array}{c}\text { Tingkat } \\
\text { Kepuasan }\end{array}$ \\
\hline 5 & Sangat Setuju & Sangat Puas \\
4 & Setuju & Puas \\
3 & Netral & Netral \\
2 & Tidak Setuju & Tidak Puas \\
1 & Sangat Tidak Setuju & Sangat Tidak \\
& & Puas \\
& & \\
& &
\end{tabular}




\section{Dinamika Lingkungan Organisasi}

Salaman dan Asch (2003) mengatakan bahwa lingkungan usaha merupakan tekanantekanan yang datang dari kompetitior. Lingkungan organisasi merupakan sekumpulan sumber daya pada di lingkungan sekitar dimana organisasi itu berada yang memiliki sifat yang tidak bisa diprediksi dan memiliki kemampuan untuk mempengaruhi keberadaan suatu organisasi. Perspektif para modernist, lingkungan organisasi adalah secara khusus diartikan menurut elemenelemennya dan terdapat beberapa cara yang berbeda untuk memisahkan elemen-elemen tersebut dan umumnya.

Ada lima faktor penting dalam lingkungan yang merupakan faktor suksesnya bisnis, yaitu lingkungan ekonomi (termasuk pajak dan peraturan), lingkungan teknologi, lingkungan kompetitif, lingkungan sosial dan lingkungan bisnis global.

Jones (1995) mengemukan bahwa sumberdaya-sumberdaya organisasi biasanya terdiri dari bahan mentah, skill pekerja dimana organisasi membutuhkannya untuk melakukan proses produksi; informasi yang dibutuhkan untuk peningkatan teknologi atau keputusan untuk mendapatkan strategi kompetisi; serta dukungan stakeholder berupa konsumen yang membeli barang dan jasa dan lembaga keuangan yang menyediakan modal bagi suatu organisasi.

Terdapat dua hal penting terkait dengan lingkungan perusahaan yakni suatu sistem yang sangat kompleks dan sejumlah komponen yang sulit untuk diprediksi dan direspon. Setiap organisasi dalam merespon lingkungannya memiliki karakteristik berbeda tergantung pada bentuk, sifat, ukuran dan budaya organisasi, terlebih antara organisasi swasta dan publik. Organisasi swasta akan melihat bahwa ketidakpastian lingkungannya sebagai fenomena yang dapat mengganggu aktivitas capaian (misalnya keuntungan), sedangkan organisasi publik cenderung melihat lingkungan yang tidak pasti dan dinamis misalnya sebagai fenomena tuntutan perubahan pelayanan publik. Besarnya lingkungan usaha yang ada dalam organisasi, maka dalam melihat proses dampak bisa mempengaruhi bagi kegiatan organisasi, sering tidak semua elemen lingkungan akan mempengaruhi organisasi, karena itu Lubis dan
Huseini (2009) mengatakan bahwa untuk keperluan analisis, lingkungan bisa diartikan sebagai seluruh elemen yang terdapat di luar batas-batas organisasi, yang mempunyai potensi untuk mempengaruhi bagian ataupun organisasi secara keseluruhan. Hal ini memberikan pemahaman bahwa terdapat perbedaan antara lingkungan organisasi swasta dan organisasi publik.

Dinamika lingkungan organisasi, baik swasta maupun publik merupakan kondisi eksternal yang sering tidak dapat dikontrol karena pergerakannya tidak dapat diperkirakan, sebagai contoh lingkungan pasar yang terkait dengan permintaan barang dan jasa yang sering mengalami fluktuasi, demikian juga dengan lingkungan organisasi publik yang menginginkan optimalisasi pelayanan yang diinginkan masyarakat, transparansi, dan good governance. Oleh karenanya suatu organisasi membutuhkan kemampuan (kapabilitas) yang cukup untuk memberikan kekuatan daya saing terhadap berbagai perubahan lingkungan tersebut baik yang sifatnya tangible dan intagible, seperti kekuatan sumberdaya (manusia), dan teknologi.

Organisasi, apapun sifatnya pasti memiliki tujuan, terlebih suatu organisasi yang sifatnya profit-oriented pasti akan memiliki tujuan yaitu untuk mendapatkan keuntungan. Secara umum organisasi merupakan kumpulan dari sekelompok orang yang memiliki pengetahuan, nilai dan visi yang tergabung dalam satu kelompok untuk mendapatkan suatu tujuan berupa penciptaan suatu nilai (value creation). Cara dan bagaimana suatu organisasi menciptakankan nilai (value creation) biasanya akan melalui tiga tahapan yaitu input, process dan output. Tahapan-tahapan tersebut akan dipengaruhi oleh lingkungan organisasi tersebut beroperasi. Sebagai contoh dalam proses input berupa, bahan baku, maka organisasi akan berupaya untuk mendapatkan suatu bahan baku yang cepat dan tepat, murah dan sesuai dengan karakteristik produk yang akan dihasilkan. Ketergantungan terhadap supplier merupakan faktor yang sangat penting dalam proses input untuk mendukung produksi. 
Setelah output (produk) dihasilkan, maka organisasi akan menghadapi ketidakpastian pasar (konsumen) dan bahkan akan menghadapi ketatnya persaingan (kompetitor).

Dalam hubungan dengan lingkungan, sifat suatu organisasi adalah tidak statik tetapi dinamis dan tidak pasti, seiring dengan pengaruh lingkungan dimana organisasi tersebut berada, dalam arti semua organisasi dalam aktivitasnya akan menghadapi ketidakpastian bahkan kompleksitas lingkungannya dimana sering seorang manajer mengalami kesulitan dalam mengontrolnya. Dalam hal ini, organisasi akan menghadapi dinamika dan perubahan lingkungan yang akhirnya membutuhkan kemampuan organisasi untuk beradaptasi dengan lingkungan tersebut.

\section{Faktor-Faktor Penyebab Dinamika Lingkungan Organisasi}

Organisasi itu ada dan tumbuh dalam suatu lingkungan dengan mana organisasi tersebut akan saling berinteraksi dan mempengaruhi satu dengan lain dalam suatu lingkungan. Lingkungan bisnis/usaha yang dihadapi oleh setiap perusahaan adalah sangat bergejolak (turbulent). Apalagi dengan mempertimbangkan kondisi internal (seperti struktur), kebanyakan organisasi sulit dalam mengantisipasi pengaruh dan dampak faktorfaktor lingkungan eksternal perusahaan. Setiap organisasi akan berinteraksi dengan lingkungannya yang memiliki karakter tidak pasti dan dinamis dan akibatnya akan bisa mempengaruhi aktivitas organisasi. Ketidakpastian ini menyebabkan tindakantindakan yang akan diambil oleh organisasi memiliki resiko kegagalan yang tinggi jika tidak diikuti dengan proses analisis yang kuat. Organisasi perlu memahami lingkungan dimana perusahaan beroperasi sepanjang lingkungan tersebut mempengaruhi aktivitas perusahaan dan organisasi harus memiliki kemampuan untuk menghadapi ketidakpastian lingkungan ini agar dapat tetap bertahan dalam lingkungannya.

Proses menganalisasi pergerakan dan kegiatan organisasi dalam suatu lingkungan mengakibatkan ketergantungan organisasi terhadap lingkungan. Hal ini dilakukan dengan pertimbangan bahwa pengaruh lingkungan terhadap organisasi memiliki sifat yang paling berpeluang untuk membahayakan atau merugikan organisasi yaitu ketidakpastian lingkungan tersebut. Kekuatan dan kemampuan organisasi untuk mempertahankan keberadaan suatu organisasi dalam ketidakpastian lingkungan sering banyak memberikan pengaruh yang sangat besar dalam upaya organisasi tersebut mencapai tujuannya. Hubungan yang kompleks antar organisasi dengan lingkungan pernah dilakukan oleh Lawrence dan Lorsch. dengan meneliti pada sepuluh organisasi dengan tiga lingkungan industri yang berbeda dan memiliki kinerja yang beragam antar masingmasing industri terhadap lingkungan dimana organisasi tersebut beraktivitas. Tujuannya adalah mencoba melihat kemampuan organisasi dalam beradaptasi dengan dinamika lingkungan usahanya yang tidak pasti.

Erik de Ward (2010) mengutip dari Lei, Hitt dan Goldhar (1996), mengemukakan bahwa selama dua dekade terakhir ini, dengan adanya perubahan teknologi yang sangat cepat, fragmentasi pasar yang terus menerus, konvergensi industri yang berbeda, semakin pendeknya siklus hidup produk, dan pertumbuhan yang sangat besar dalam bidang telekomunikasi mengakibatkan lingkungan kompetitif organisasi semakin turbulen. Semakin turbulennya lingkungan bisnis ini, mengakibatkan organisasi harus mampu untuk mengatasi lingkungan bisnis tersebut yang memiliki dinamika yang tinggi, kompleks dan sulit untuk diprediksi pada saat yang sama (Volberda dan Elfring, 1996) yang akhirnya mempengaruhi perkembangan bidang manajemen stratejik dengan suatu proses penye-suaian terhadap perkembangan lingkungan eksternal serta situasi internal organisasi.

Terdapat tiga faktor yang meningkatkan ketidak pastian lingkungan adalah kompleksitas (complexity), dinamisme (dynamism) dan kekayaan lingkungan (richness of environment) (Jones, 1995) atau environmental complexity, environmental stability dan environmental richness (Cunliffe, 2008). Faktor-faktor ini merupakan kesatuan yang tidak bisa dipisahkan dalam lingkungan dan selalu 
bersifat sangat fleksibel serta saling mempengaruhi satu dengan yang lain.

Kompleksitas (complexity) lingkungan merupakan fungsi dari pada kekuatan, jumlah dan ketersediaan sumberdaya-sumberdaya yang ada di lingkungan dimana organisasi harus mengolahnya, dinamisme (dynamism) lingkungan merupakan fungsi daripada cepat lambatnya perubahan-perubahan yang terjadi dalam lingkungan yang sifatnya spesifik maupun umum sedangkan kekayaan lingkungan (richness of environment) merupakan seberapa banyak ketersediaan semua sumberdaya yang ada di lingkungan untuk mendukung aktivitas suatu organisasi. Perubahan lingkungan bisnis akan terjadi setiap saat, umumnya berupa gerak perubahan dari salah satu atau gabungan dari faktorfaktor lingkungan luar perusahaan. Sebagian dari dampak yang ditimbulkan banyak terbukti telah mempengaruhi datangnya berbagai kesempatan usaha (business opportunities). Jika dikaitkan dengan bentuk dan struktur organisasi, jika perusahaan dengan bentuk dan struktur yang baik dengan sistem organisasi yang baik dengan dukungan visi, misi dan rencana aksi business plan yang terencana belum bisa menjamin sukses dalam mencapai tujuannya.

Jianwey, et al.,(2009) mengutip dari Miles dan Snow (1978) dan Learned et al., (1965) mengatakan bahwa pertimbangan utama organisasi dalam menghadapi dinamika lingkungan adalah bagaimana organisasi harus berupaya untuk mencari strategi-strategi agar organisasi cocok dengan lingkungannya, dan organisasi harus memiliki perhatian utama dari semua strategi dan manajemen organisasi untuk mempertahankan Dynamic Fit antara apa yang organisasi tawarkan dan apa yang lingkungan atur berupa sejumlah faktor atau elemen yang berada di luar organisasi. Perusahaan harus melakukan adaptasi dan eksplorasi perubahan-perubahan dari sejumlah faktor dan elemen dalam lingkungan bisnisnya serta mencari kesempatan untuk melakukan perubahan dengan penggunaan teknologi, organisasional dan stratejik inovasi.

\section{Perumusan Masalah}

Berdasarkan latar belakang yang telah dipaparkan, maka yang menjadi permasalahan dalam penelitian ini bagaimana daya saing usaha kacang goyang yang ada di UD.Beusaha dan UD. Kabela di Kotamobagu?

\section{Tujuan dan Manfaat Penelitian}

Penelitian ini bertujuan untuk menganalisis daya saing industri kacang goyang UD. Berusaha dan UD. Kabela Kotamobagu.

Adapun manfaat penulisan penelitian ini diharapkan dapat menjadi bahan masukan bagi pihak yang ingin melakukan investasi pada industri kacang goyang dan bisa menjadi bahan referensi bagi penelitian selanjutnya yang terkait dengan pengembangan perusahaan kacang.

\section{METODE PENELITIAN}

\section{Waktu dan Tempat Penelitian}

Penelitian ini dilaksanakan di kelurahan Motoboi Kecil Kecamatan Kotamobagu Selatan Kota Kotamobagu selama 4 bulan yaitu dari bulan Juli sampai bulan November 2015.

\section{Jenis dan Sumber Data}

Data yang di peroleh dalam penelitian ini meliputi data primer dan sekunder. Pengumpulan data primer dilaksanakan dengan mengunakan daftar pertanyaan sedangkan data sekunder diambil dari instansi-instansi yang terkait langsung dengan penelitian seperti Dinas Pertanian.

\section{Metode Pengumpulan Data}

Metode yang digunakan dalam penelitian ini adalah metode survey. Dengan menyebarkan kusioner langsung kepada responden. Jumlah responden yang diambil sebanyak 60 responden dengan jumlah masing-masing UD sebanyak 30 responden secara sengaja (purposive sampling). 


\section{Konsep Pengukuran Variabel}

Pengukuran daya saing dari usaha ini didasarkan pada variabel-variabel berikut yang diukur dengan menggunakan skala Likert dengan kategori lima skala yaitu 1 (sangat tidak puas), 2 (tidak puas), 3 (netral), 4 (puas) dan 5 (sangat puas).

1. Karakteristik responden
a. Jenis kelamin ( laki-laki/perempuan )
b. Umur
c. Pekerjaan
d. Pendidikan terakhir
e. Frekuensi Kunjungan

2. Harga

Indikator variabel harga adalah :
a. Terjangkau atau tidaknya harga
b. Kesesuaian harga dengan kapasitas isi
c. Kesesuaian harga dengan cita rasa
d. Kesesuaian harga dengan manfaat
e. Kesesuaian harga dengan kualitas

3. Pelayanan

Indikator variabel pelayanan adalah :

a. Kualitas pelayanan atau keandalan jasa pelayanan (reliability) yaitu kecepatan dalam melayani pembelian kacang goyang

b. Daya tanggap (responsiveness) yaitu kesigapan karyawan dalam memberikan pelayanan dan menangani keluhan para konsumen kacang goyang

c. Keyakinan (assurance) yaitu pengetahuan karyawan terhadap produk kacang goyang yang dijual

d. Penampilan fisik (tangible) yaitu penampilan fisik dari karyawan

e. Empati (emphaty) yaitu keramahan karyawandalam melayani konsumen.

4. Produk

Indikator variabel produk adalah :

a. Kebersihan dalam penyajian

b. Ketersediaan dan kelengkapan produk kacang goyang

c. Cita rasa produk

d. Tampilan fisik produk

e. Tingkat kepuasan dari konsumen

5. Tempat

Indikator variabel tempat adalah :
a. Kebersihan ruangan
b. Kenyamanan ruangan
c. Tampilan fisik ruangan
d. Kelengkapan sarana dan fasilitas yang dimiliki
e. Lokasi yang strategis.

\section{HASIL DAN PEMBAHASAN}

\section{Deskripsi Umum Usaha UD. Berusaha dan UD. Kabela}

Kacang goyang UD Berusaha terletak di Kelurahan Motoboi Kecil, Kecamatan Kotamobagu Selatan, Kota Kotamobagu Provinsi Sulawesi Utara. Sarana transportasi ke kawasan ini cukup baik dengan kondisi jalan yang lebar dan dapat dilalui oleh kendaraan besar dan kecil, selain itu daerah ini memiliki fasilitas yang diperlukan oleh perusahaan seperti fasilitas listrik oleh PLN, telekomunikasi serta fasilitas air. Perusahan Kacang Goyang UD. Berusaha merupakan salah satu perusahaan yang bergerak dalam bidang industri yang menghasilkan produk berupa kacang goyang, didirikan oleh Bapak Hidar Kombandaha (2000), Perusahaan Kacang Goyang UD. Berusaha berlokasi di jalan Darusalam, di Motoboi Kecil Kecamatan Kotamobagu Selatan.

Sedangkan UD. Kabela terletak di Lingkungan IV, Kelurahan Motoboi Kecil pertama kali didirikan oleh Ibu Frida Mokoagow beserta keluarganya. Bermula dari usaha kecil-kecilan, kini usaha yang didirikan sudah berkembang menjandi suatu badan usaha yang bernama UD. Kabela, dan sekarang sudah memasarkan hasil tidak hanya di Daerah Sulawesi Utara tapi sudah meramba ke luar daerah

Sumber daya manusia merupakan salah satu fakor yang sangat menentukan pertumbuhan usaha. Sumber daya yang dimaksud adalah pengusaha dan tenaga kerja yang berada dalam usaha agroindustri kacang goyang Motoboi kecil. Tenaga kerja pada industri kacang Goyang UD. Berusaha berjumlah 32 orang, yang mana pada bagian sangrai berjumlah 2 orang, pengupasan kulit ari 10 orang, penggoyangan 16 dan pengepakan 4 orang. Sedangkan UD. Kabela mempekerjakan karyawan sebanyak 20 orang. Pada bagian sangrai 2 orang, pengupasan kulit ari 8 orang, penggoyangan 8 orang dan pengepakan 2 orang. 


\section{Karakteristik Responden}

Karakteristik responden yaitu untuk memberikan gambaran tentang keadaan diri responden. Responden dalam penelitian ini yaitu konsumen yang secara kebetulan bertemu dan membeli produk kacang goyang yang berjumlah 60 orang. Gambaran keadaan responden meliputi jenis kelamin, usia, pendidikan terakhir, pekerjaan dan frekuensi berkunjung.

\section{Jenis Kelamin Responden}

Jenis kelamin responden bisa menjadi penentu atas tindakan atau perilaku responden dalam membeli barang atau jasa. Berikut Tabel 2 jenis kelamin responden:

\section{Tabel 2. Jenis Kelamin Responden} Pabrik Kacang Goyang

\begin{tabular}{ccc}
\hline Jenis & $\begin{array}{c}\text { Jumlah } \\
\text { Kelamin }\end{array}$ & $\begin{array}{c}\text { Presentase } \\
(\%)\end{array}$ \\
\hline Laki-laki & 21 & 35 \\
Perempuan & 39 & 65 \\
\hline Jumlah & $\mathbf{6 0}$ & $\mathbf{1 0 0}$ \\
\hline Sumber $:$ Diolah dari Data Primer, 2015
\end{tabular}

Tabel 2 menunjukkan bahwa untuk jenis kelamin perempuan memiliki jumlah yang lebih banyak dibandingkan dengan jenis kelamin laki-laki yaitu laki-laki 21 orang (35\%) dan perempuan 39 orang (65\%). Hal ini menunjukkan bahwa perempuan lebih banyak membeli kacang goyang di pabrik kacang goyang untuk keperluan dirumah sebagai cemilan ataupun untuk buah tangan.

\section{Usia Responden}

Banyaknya pengunjung di pabrik kacang goyang bervariasi berdasarkan usia. Usia juga seringkali menjadi penentu dalam pengambilan keputusan pembelian. Dapat dilihat pada Tabel 3. Tabel 3 menunjukkan bahwa responden terbanyak adalah berusia 4150 tahun yaitu 24 orang (40\%), sedangkan presentasi terkecil yaitu pada usia 20-30 tahun sebanyak 5 (9\%). Ini menunjukkan responden terbanyak pada usia 41-50 tahun, pada usia ini lebih banyak membeli untuk dimakan bersama keluarga dan untuk dijual.
Tabel 3. Usia Responden Pabrik Kacang Goyang

\begin{tabular}{ccc}
\hline $\begin{array}{c}\text { Golongan } \\
\text { Umur } \\
\text { Responden } \\
\text { (Tahun) }\end{array}$ & $\begin{array}{c}\text { Jumlah } \\
\text { Responden }\end{array}$ & $\begin{array}{c}\text { Presenta } \\
\text { se (\%) }\end{array}$ \\
\hline $20-30$ & 5 & 9 \\
$31-40$ & 14 & 23 \\
$41-50$ & 24 & 40 \\
$>50$ & 17 & 28 \\
\hline Jumlah & $\mathbf{6 0}$ & $\mathbf{1 0 0}$ \\
\hline Sumber : Diolah dari Data Primer, 2015
\end{tabular}

\section{Tingkat Pendidikan Responden}

Pendidikan seseorang seringkali menjadi penentu perilaku seseorang dalam pengambilan keputusan pembelian dapat dilihat pada Tabel 4.

Tabel 4 menunjukkan bahwa responden terbanyak adalah lulusan starata satu dengan jumlah responden $31(40 \%)$ dan diikuti oleh responden lulusan SMA dengan jumlah 10 orang (34\%). Kemudian diikuti oleh responden dengan lulusan D3 dengan jumlah 8 orang (11\%.) Sedangkan jumlah responden dengan lulusan SD dengan jumlah 2 orang (3\%). Ini menunjukkan bahwa responden berdasarkan pendidikan kebanyakan adalah berpendidikan S1.

Tabel 4. Tingkat Pendidikan Responden Pabrik Kacang Goyang

\begin{tabular}{lcc}
\hline $\begin{array}{c}\text { Tingkat } \\
\text { Pendidikan }\end{array}$ & $\begin{array}{c}\text { Jumlah } \\
\text { Responden }\end{array}$ & $\begin{array}{c}\text { Persentase } \\
(\boldsymbol{\%})\end{array}$ \\
\hline SD & 2 & 3 \\
SMP & 8 & 12 \\
SMA/SMK & 10 & 34 \\
S1 & 31 & 40 \\
D3 & 8 & 11 \\
\hline \multicolumn{1}{c}{ Jumlah } & $\mathbf{6 0}$ & $\mathbf{1 0 0}$ \\
\hline \multicolumn{2}{c}{ Sumber : Diolah dari Data Primer, 2015}
\end{tabular}

\section{Pekerjaan Responden}

Pekerjaan pada umumnya mencerminkan satu bentuk perilaku pembelian terhadap produk atau jasa. Tabel 5 menunjukkan bahwa responden terbanyak adalah 
PNS dengan jumlah 27orang (45\%) sedangkan responden terkecil adalah supir bentor 2 orang (3\%) dan pelajar/mahasiswa 3 orang (5\%). Ini menunjukkan bahwa kebanyakan responden adalah PNS.

Tabel 5. Pekerjaan Responden

\begin{tabular}{lcc}
\hline $\begin{array}{c}\text { Jenis } \\
\text { Pekerjaan }\end{array}$ & $\begin{array}{c}\text { Jumlah } \\
\text { Respon- } \\
\text { den }\end{array}$ & $\begin{array}{c}\text { Presentase } \\
(\%)\end{array}$ \\
\hline Pelajar/Maha- & 3 & 5 \\
siswa & & \\
PNS & 27 & 45 \\
Wiraswasta & 3 & 5 \\
Swasta & 5 & 9 \\
Pensiun & 13 & 22 \\
Sopir Bentor & 2 & 3 \\
Tidak Bekerja & 7 & 11 \\
\hline \multicolumn{1}{c}{ Jumlah } & $\mathbf{6 0}$ & $\mathbf{1 0 0}$ \\
\hline
\end{tabular}

Sumber : Diolah dari Data Primer, 2015

\section{Frekuensi Kunjungan Responden}

Frekuensi kunjungan responden pabrik kacang goyang dilaksanakan selama dua bulan dari bulan mei 2015 - juli 2015 untuk mengetahui seberapa banyak konsumen yang datang membeli kacang goyang. Berikut Table 6 frekuensi kunjungan responden.

Tabel 6 menunjukkan bahwa konsumen terbanyak yang berkunjung lebih dari 2-5 kali degan jumlh responden 30 orang (50\%) sedangkan yang terkecil adalah responden dengan jumlah kunjungan $\geq 11$ yaitu sebanyak 5 orang (8\%). Ini me-nunjukkan bahwa responden yang berkunjung lebih dari 2-5 kali sudah sering membeli di pabrik kacang goyang membeli kacang goyang.

Responden yang baru pertama kali mengunjungi pabrik kacang goyang menyatakan akan datang lagi membeli kacang goyang karena rasanya enak, manis, gurih, harganya yang terjangkau. Sedangkan responden yang datang sudah lebih dari satu kali berkunjung di pabrik kacang goyang menyatakan bahwa rasanya enak dan kualitas produknya tidak pernah berubah dari tahun ke tahun, bisa dibuat cemilan, praktis dibawa kemana saja dan bisa dibuat oleh-oleh.
Tabel 6. Frekuensi Kunjungan Responden

\begin{tabular}{ccc}
\hline Kunjungan & $\begin{array}{c}\text { Jumlah } \\
\text { Responden }\end{array}$ & $\begin{array}{c}\text { Presentase } \\
(\%)\end{array}$ \\
\hline 1 & 10 & 17 \\
$2-5$ & 30 & 50 \\
$6-10$ & 15 & 25 \\
$>10$ & 5 & 8 \\
\hline Jumlah & $\mathbf{6 0}$ & $\mathbf{9 0}$ \\
\hline Sumber : Diolah dari Data Primer, 2015
\end{tabular}

\section{Pengukuran Daya Saing Pada UD. Berusaha dan UD. Kabela}

Pengukuran daya saing pada UD. Berusaha dan UD. Kabela dilakukan dengan menggunakan analisis IPA dengan be-berapa variabel yaitu : produk, harga, tempat, dan pelayanan.

\section{Produk}

Produk merupakan hasil produksi dalam suatu usaha. Produk juga merupakan salah satu aspek yang menentukan dalam kegiatan suatu usaha, karena tanpa produk suatu perusahaan tidak dapat melakukan kegiatan untuk mencapai hasil yang diharapakan. Produk suatu perusahaan haruslah memiliki suatu keunggulan atau kelebihan dibandingkan dengan produk yang dihasilkan perusahaan lain. Suatu produk tidak dapat dilepaskan dari kepuasan kebutuhan dan keinginan konsumen. Jumlah suatu produk yang dihasilkan tergantung dari sumber daya yang ada dalam suatu perusahaan dan akan mempengaruhi harga dan penjualan.

Penilaian berdasarkan jumlah penjualan produk pada kedua usaha ini dinilai berdasarkan lima variabel yaitu kebersihan dalam penyajian produk kacang goyang, ketersediaan produk kacang goyang, cita rasa produk kacang goyang, tampilan fisik produk kacang goyang, kelengkapan dan ketersediaan produk kacang goyang, yang dijelaskan dengan menggunakan kurva IPA

Penjelasan tentang kelima pengukuran dari UD. Berusaha dan UD. Kabela dapat dilihat pada Gambar 2. 
Gambar 2 menjelaskan tentang posisi daya saing dari kedua UD tersebut dimana dapat dijelaskan tentang penilaian jumlah penjualan berdasarkan kelima aspek tersebut terkait dengan kualitas produk dari UD. Berusaha dan UD. Kabela. Secara umum kedua UD tersebut berada pada kuadran B yaitu 'Keep Up the Good Work ' atau produk dari kedua UD tersebut menunjukkan bahwa produk wajib dipertahankan dan dianggap sangat penting dan memuaskan, kecuali pada titik yang kelima yaitu kelengkapan dan ketersedian produk dari UD. Berusaha berada pada kuadran A yaitu 'Concentrate Here' atau produk dari UD. Berusaha yang menunjukkan Faktor yang dianggap mempengaruhi pelanggan, dianggap sangat penting. Namun, produk tidak sesuai keinginan pelanggan sehingga tidak puas. Berdasarkan penjelasan Gambar 2 maka disimpulkan bahwa untuk pelayan produk baik untuk UD. Berusaha dan UD. Kabela pada kuadran diatas menunjukkan bahwa sangat puas dengan kebersihan dalam penyajian produk kacang goyang, tampilan fisik atau bentuk dari kacang goyang juga sangat bagus. Sangat puas juga dengan cita rasa produk kacang goyang yang tidak pernah berubah dari tahun ke tahun yang enak dan gurih serta kelengkapan dan ketersedian produk puas karena bahan yang dipakai untuk membuat kacang goyang sangat berkualitas dan juga perlengkapan dalam pabrik sangat terjamin walaupun diolah sendiri memakai alat yang sederhana tetapi kualitasnya terjamin.

Gambar 2. Kurva IPA Produk UD. Berusaha dan UD. Kabela

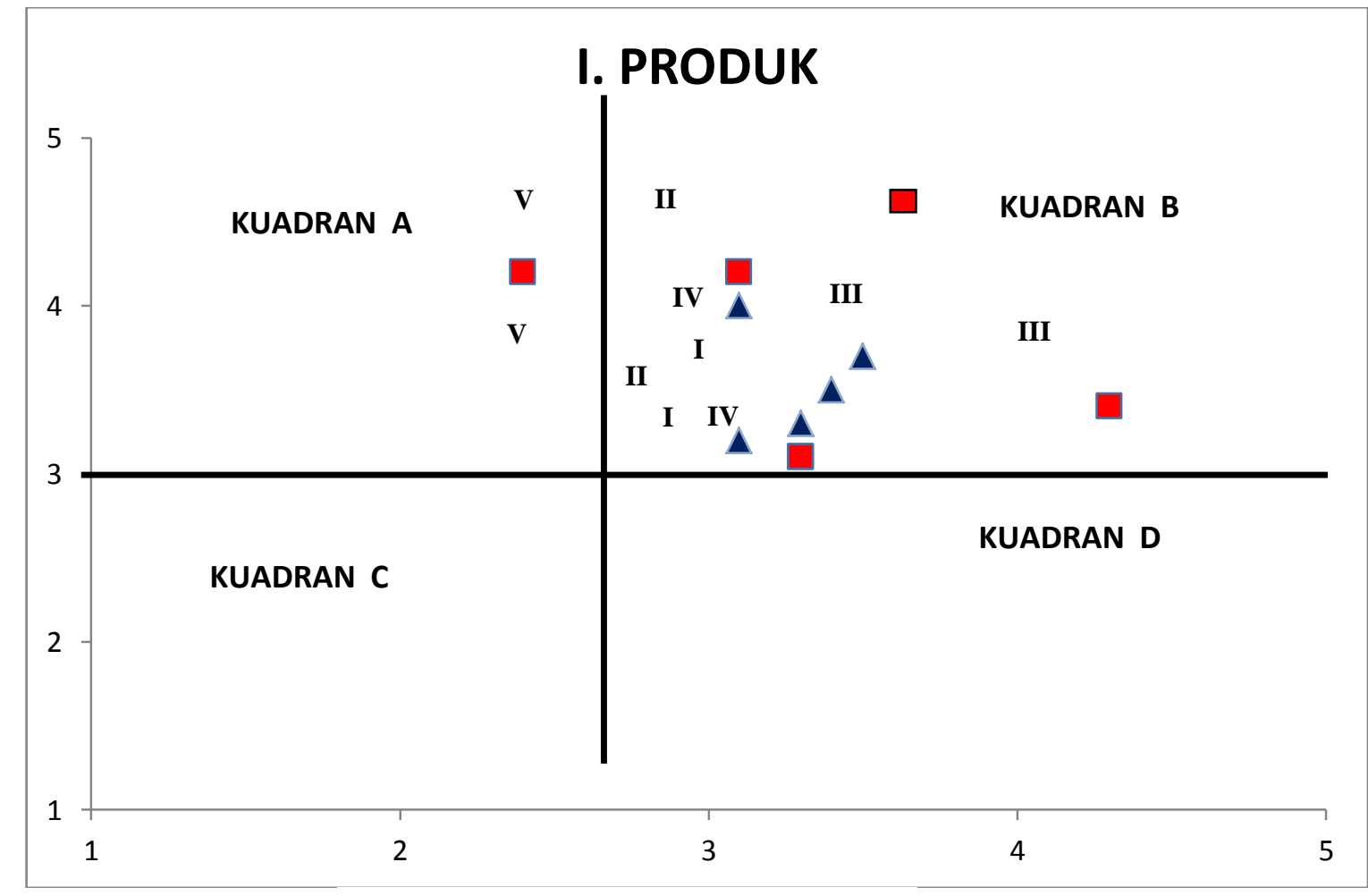

\section{UD. BERUSAHA}

Ket $\quad$ : Titik I (Kebersihan) $\quad:(3,3 \& 3.1)$

Titik II (Ketersediaan) : (3.1 \& 4.2)

Titik III (Cita Rasa) : : (4.3 \& 3.4)

Titik IV (Tampilan) $\quad:(3.3 \& 3.1)$

Titik V (Kelengkapan) : $(4.0 \& 4,2)$
UD.

KABELA
Titik I (Kebersihan) : ( $3.3 \& 3.3)$

Titik II (Ketersediaan) : (3.1\& 3.2)

Titik III (Cita Rasa) : $\quad$ (3.5 \& 3.7)

Titik IV (Tampilan) : $\quad$ (3.4 \& 3.5)

Titik V (Kelengkapan) : (3.1\& 4.0) 
Gambar 3. Kurva IPA Harga UD. Berusaha dan UD. Kabela

IMPORTANCE

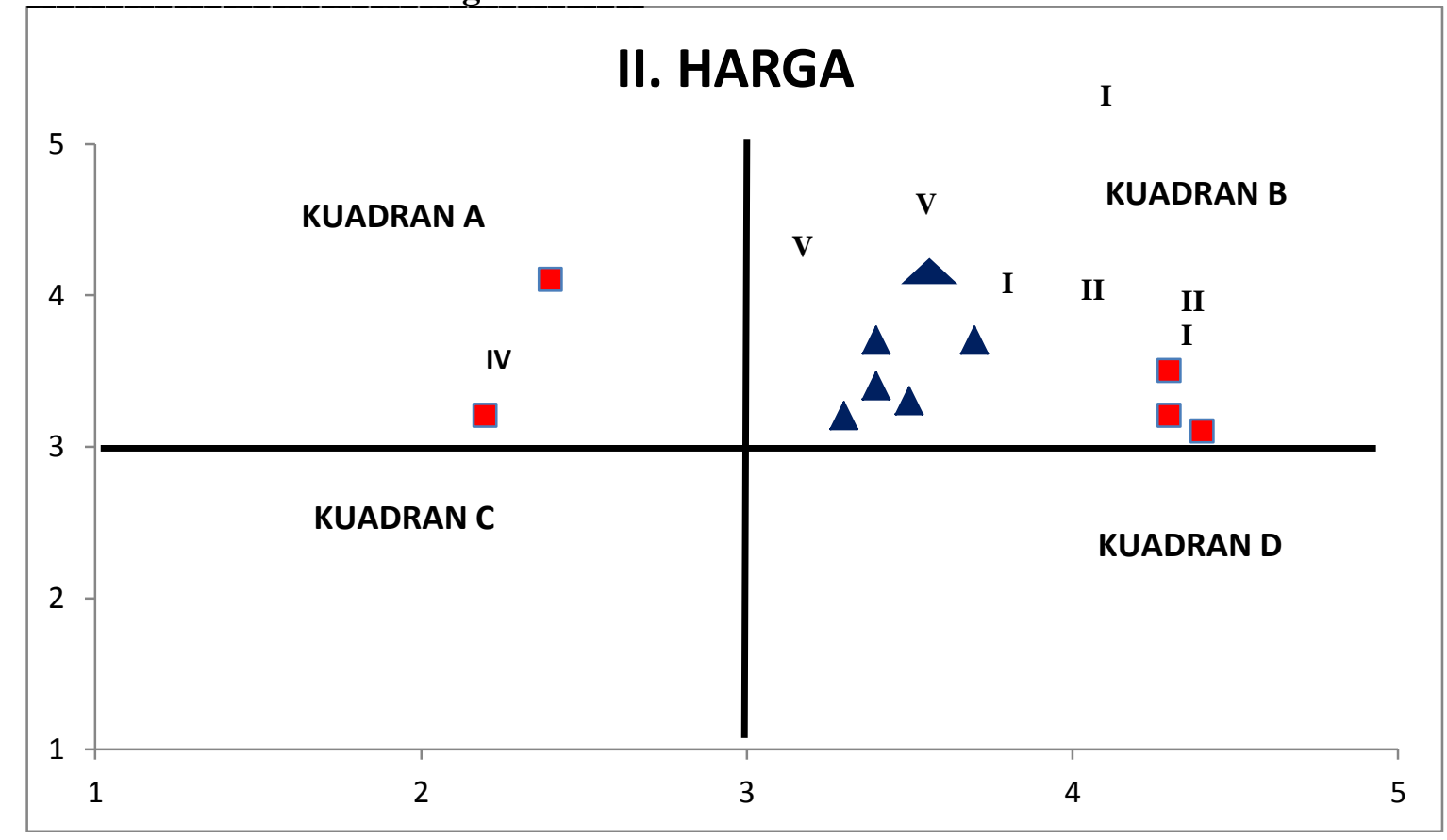

\section{PERFORMANCE}

Ket

$\begin{array}{ll}\text { : Titik I (Terjangkau) } & :(4,3 \& 3.5) \\ \text { Titik II (Kapasitas Isi) } & :(4.4 \& 3.1) \\ \text { Titik III ( Cita Rasa) } & :(4.3 \& 3.2) \\ \text { Titik IV (Manfaat Produk) } & :(2.2 \& 3.2) \\ \text { Titik V (Kwalitas Produk) } & :(2.4 \& 4,1)\end{array}$

\section{Harga}

Harga merupakan salah satu bagian yang sangat penting dalam pemasaran suatu produk, harga juga merupakan penentu keberhasilan suatu perusahaan karena harga menentukan seberapa besar keuntungan yang akan diperoleh perusahaan dari penjualan produknya baik berupa barang ataupun jasa. Menetapkan harga terlalu tinggi akan menyebabkan harga turun. namun jika harga rendah akan mengurangi keuntungan yang diperoleh oleh perusahaan.

Dengan melihat definisi harga diatas dapat disimpulkan bahwa harga adalah sejumlah uang yang harus dikeluarkan oleh konsumen untuk mendapatkan produk atau jasa yang dibelinya guna memenuhi kebutuhan dan keinginannya.

Pengukuran variabel harga berdasarkan pada terjangkau atau tidaknya harga, kesesuain harga dan kapasitas isi, kesesuaian harga dan cita rasa, kesesuaian harga dengan manfaat yang diperoleh dari pro-

$\begin{array}{ll}\text { Titik I (Terjangkau) } & :(3.7 \& 3.7) \\ \text { Titik II (Kapasitas Isi) } & :(3.4 \& 3.4) \\ \text { Titik III ( Cita Rasa) } & :(3.4 \& 3.7) \\ \text { Titik IV (Manfaat Produk) } & :(3.3 \& 3.2) \\ \text { Titik V (Kwalitas Produk) } & :(3.5 \& 3.3)\end{array}$

duk kacang goyang, dan kesesuaian harga dengan kualitas dari produk kacang goyang. Penjelasan tentang kelima peng-ukuran dari UD. Berusaha dan UD. Kabela dapat dilihat pada kurva Gambar 3.

Gambar 3 dapat dijelaskan tentang penilaian jumlah penjualan berdasarkan kelima aspek tersebut terkait dengan kualitas harga dari UD. Berusaha dan UD. Kabela. Secara umum kedua UD tersebut berada pada kuadran B yaitu "Keep Up the Good Work" atau harga dari kedua UD tersebut menunjukkan bahwa harga wajib dipertahankan dan dianggap sangat penting dan memuaskan, kecuali data aspek yang keempat dan kelima yaitu kesesuaian harga dengan manfaat yang didapat dari produk kacang goyang dan kesesuaian harga dengan kualitas dari produk kacang goyang UD Berusaha berada pada kuadran A sebagai 'Concentrate Here' atau produk dari UD. Berusaha menunjukkan faktor yang dianggap mempengaruhi pe- 
langgan, dianggap sangat penting, namun produk tidak sesuai keinginan pelanggan sehingga tidak puas. Gambar 3, menyatakan puas dengan harga yang ditawarkan sesuai dengan harga kacang goyang yang terjangkau dengan kantong konsumen, harga yang sesuai dengan kapasitas isi produk kacang goyang sesuai dengan harganya, harga yang sesuai dengan cita rasa dari produk kacang goyang yang tidak pernah berubah dari tahun ke tahun, kuadran diatas juga menjelaskan bahwa puas dengan kualitas dan manfaat yang diperoleh karena kualitas dari produk kacang goyang yang tahan lama tidak cepat basi dan juga rasanya yang gurih dan manis bisa digunakan sebagai cemilan bersama keluarga, menyambut tamu ketika hari raya seperti hari natal, lebaran ataupun hari besar lainnya, dan juga bisa menjadi buah tangan.

\section{Tempat}

Tempat adalah suatu tempat yang umumnya terdapat banyak orang yang berkumpul untuk melakukan suatu kegiatan baik secara sementara maupun secara terus menerus dan baik membayar maupun tidak membayar. Tempat juga dapat diartikan sebagai sarana yang diselenggarakan oleh pemerintah, swasta atau perorangan yang digunakan untuk kegiatan bagi masyarakat. Tempat berkaitan dengan fasilitas yang ditawarkan kepada konsumen.

Pengukuran variabel tempat berdasarkan pada kebersihan ruangan di pabrik kacang goyang, kenyamanan ruangan pabrik kacang goyang, tampilan fisik ruangan pabrik kacang goyang, kelengkapan sarana dan fasilitas yang dimiliki pabrik kacang goyang, dan lokasi tempat pemasaran. Penjelasan tentang kelima pengukuran dari UD. Berusaha dan UD. Kabela dapat dilihat pada kurva yang ada pada Gambar 4.

Gambar 4 dapat dijelaskan tentang penilaian jumlah penjualan berdasarkan kelima aspek tersebut terkait dengan tempat dari UD. Berusaha dan UD. Kabela. Secara umum kedua UD tersebut berada pada kuadran B yaitu 'Keep Up the Good Work' atau tempat dari kedua UD tersebut menunjukkan bahwa tempat wajib dipertahankan dan dianggap sangat penting dan memuaskan, kecuali data aspek yang ketiga tampilan fisik ruangan pabrik, ke-empat kelengkapan sarana dan fasilitas dan kelima lokasi tempat pemasaran strategis UD. Berusaha ada dikuadran D yaitu 'Possible Overkill' atau menunjukkan bahwa dianggap kurang penting tetapi berlebihan atau sangat memuaskan.

Berdasarkan Gambar 4, juga diketahui bahwa tanggapan terhadap tempat pabrik UD. Berusaha dan UD. Kabela yaitu puas. Adapun tanggapan tentang kenyamanan ruangan pabrik keduanya berada pada kuadran $b$ yaitu sangat memuaskan, sedangkan untuk kelengkapan fasilitas dan ketersedian tempat parkir berada pada kuadran d yaitu kurang penting tapi sangat memuaskan yang artinya perlu ditingkatkan lagi karena tempat parkir yang berada di pabrik kacang goyang sangat sempit sehingga kendaraan yang datang untuk membeli sering kali hanya memarkir kendaraanya dijalan fasilitas yang dimiliki oleh pabrik juga belum memadai, kiranya ruangan pabrik kacang goyang bisa diperluas dan diberi tempat duduk sehingga konsumen bisa menunggu, begitu juga dengan lokasi pemasaraan yang kurang strategis sehingga konsumen sedikit susah mencari lokasi pabrik kacang goyang yang berada di Kotamobagu, sedangkan kebersihan ruangan dan tampilan fisik pabrik mendapat nilai sangat puas, karena pihak pabrik sangat mengutamakan kebersihannya.

\section{Pelayanan}

Pelayanan merupakan kemudahan yang diberikan sehubungan dengan proses jual beli barang dan jasa. Pelayanan juga adalah sebuah proses pemenuhan kebutuhan melalui aktifitas orang yang menyangkut segala usaha yang dilakukan orang lain dalam rangka mencapai tujuannya.

Pengukuran variabel pelayanan berdasarkan pada kecepatan dalam melayani 
konsumen, kesigapan karyawan dalam memberikan pelayanan dan menangani keluhan konsumen, pengetahuan karyawan mengenai produk kacang goyang, penampilan fisik dari karyawan (kerapian berpakaian), dan keramahan karyawan dalam melayani konsumen.

Penjelasan tentang kelima pengukuran dari UD. Berusaha dan UD. Kabela dapat dilihat pada Gambar 5. Pada Gambar 5 dapat dijelaskan tentang penilaian jumlah penjualan ber-dasarkan kelima aspek tersebut terkait dengan kualitas produk dari UD. Berusaha dan UD. Kabela. Secara umum kedua UD tersebut berada pada kuadran B yaitu 'Keep Up the Good Work', kecuali pada titik yang pertama yaitu kecepatan dalam melayani konsumen di pabrik kacang goyang dari UD. Berusaha berada pada kuadran A yaitu 'Concentrate Here' atau pelayanan dari UD. Berusaha dianggap sangat penting, namun produk tidak sesuai keinginan pelanggan sehingga tidak puas.
Tanggapan terhadap pelayanan produk kacang goyang adalah sangat puas yang artinya rata-rata dilihat dari Gambar 5, sangat puas dengan pelayanan dipabrik kacang goyang. Hal ini didukung oleh adanya perhatian yang cukup baik dari pihak pabrik kacang goyang kepada konsumen. Adapun tanggapan mengenai kecepatan dalam penyajian kacang goyang adalah puas, kesigapan karyawan dalam memberikan pelayanan. Pengetahuan karyawan tentang kacang goyang dan keramahan karyawan kepada konsumen yaitu puas karena kecepatan dalam penyajian, kesigapan keryawan, pengetahuan karyawan, dan keramahan kar-yawan sangatlah diutamakan sehingga konsumen tidak beralih ke produk yang lain. Namun penampilan fisik karyawan masih belum memuaskan. Pihak dari industri kacang goyang harus memperhatikan lagi penampilan karyawan, dari pakaian dan juga terutama bagi perempuan harus diikat rambutnya agar terlihat rapi.

\section{Gambar 4. Kurva Tempat UD. Berusaha dan UD. Kabela}

\section{IMPORTANCE}

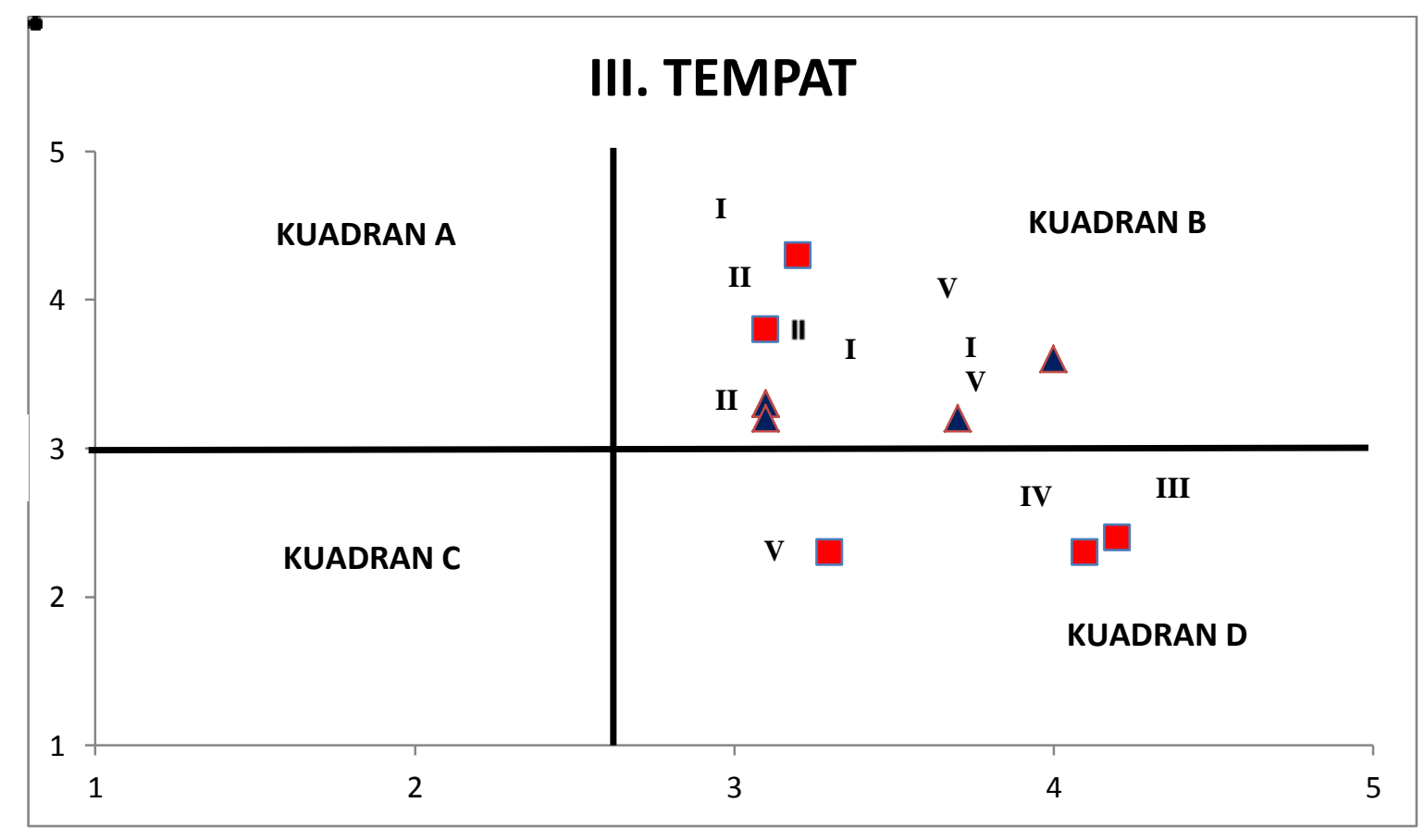

PERFORMANCE

$\begin{array}{ll}\text { Titik I (Kebersihan) } & :(3.7 \& 3.2) \\ \text { Titik II (Kenyamanan) } & :(3.1 \& 3.3) \\ \text { Titik III (Tampilan) } & :(3.1 \& 3.3) \\ \text { Titik IV (Fasilitas) } & :(3.1 \& 3.2) \\ \text { Titik V (Lokasi) } & :(4.0 \& 3.6)\end{array}$




\section{IMPORTANCE}

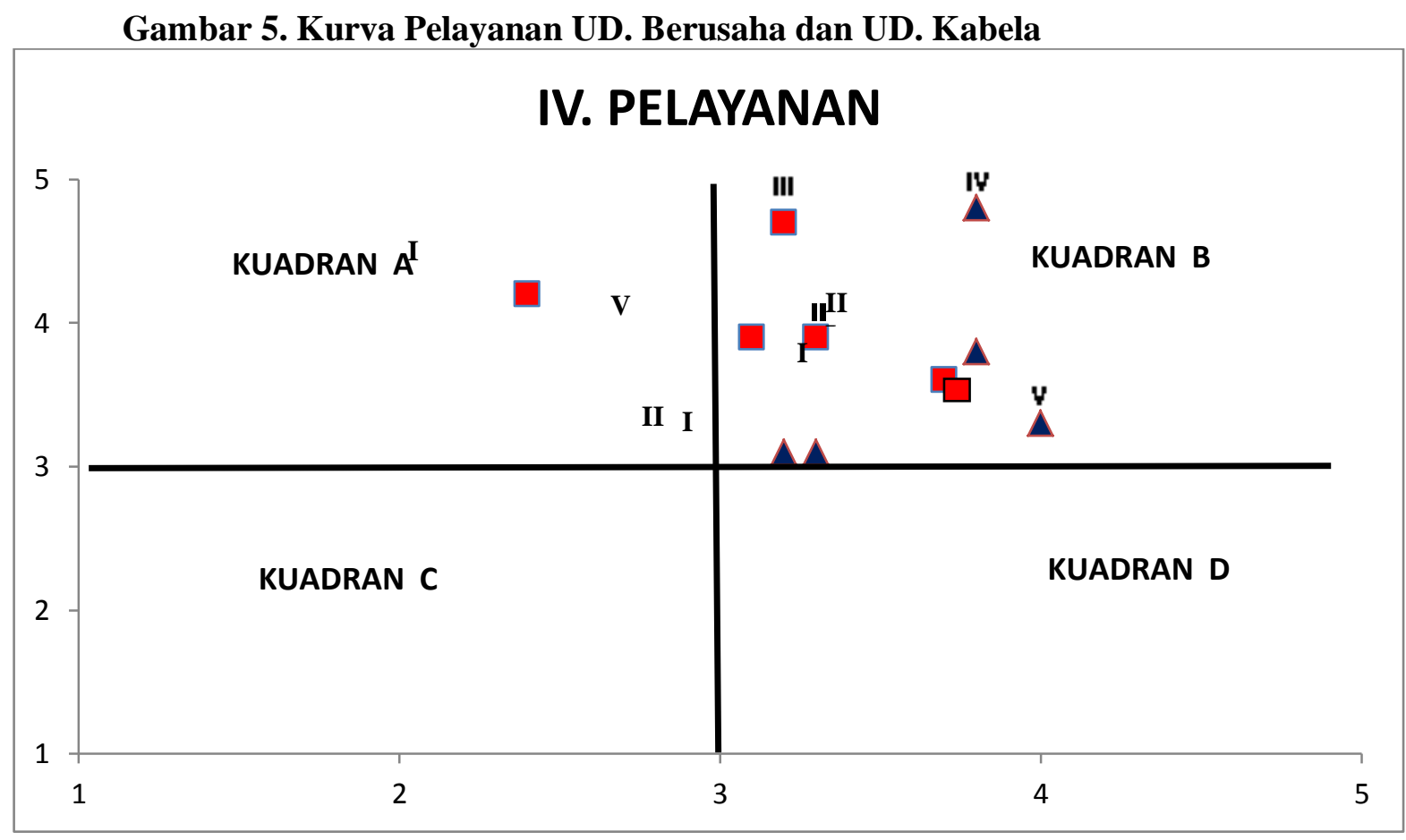

\section{PERFORMANCE}

$\begin{array}{ll}\text { Ket } \quad: \text { Titik I (Kecepatan) } & :(2.4 \& 4.2) \\ \text { Titik II (Kesigapan) } & :(3.3 \& 3.9) \\ \text { Titik III (Pengetahuan) } & :(3.2 \& 4.7) \\ \text { Titik IV (Kerapian) } & :(3.7 \& 3.6) \\ \text { Titik V (Keramahan) } & :(3.1 \& 3.9)\end{array}$

\section{KESIMPULAN DAN SARAN}

\section{Kesimpulan}

Dari hasil penelitian diperoleh bahwa pelayan Produk baik untuk UD. Berusaha dan UD. Kabela menunjukkan tingkat kepuasaan terhadap pembeli baik dari segi kebersihan, tampilan, dan bentuk dari penyajian kacang goyang tersebut. Dari segi Harga yang ditawarkan oleh UD. Berusaha dan UD. Kabela menunjukkan bahwa harga yang ditawarkan terjangkau, kemudian harga sesuai isi produk dan cita rasa sehingga para pembeli boleh merasa puas dengan harga yang ditetapkan. dari segi Tempat yang digunakan UD. Berusaha dan UD. Kabela baik dari tingkat kebersihan dan kenyamanan sudah sangat memuaskan pembeli, hanya ada beberapa aspek yang perlu dibenahi oleh pabrik demi meningkatkan kepuasan pembeli

$\begin{array}{ll}\text { Titik I (Kecepatan) } & :(3.3 \& 3.1) \\ \text { Titik II (Kesigapan) } & :(3.2 \& 3.1) \\ \text { Titik III (Pengetahuan) }) & :(3.8 \& 3.8) \\ \text { Titik IV (Kerapian) } & :(3.8 \& 4.8) \\ \text { Titik V (Keramahan) } & :(4.0 \& 3.3)\end{array}$

yaitu ketersediaan tempat parkir yang luas serta lokasi pemasaran yang belum strategis.

Dari segi Pelayanan yang diberikan oleh karyawan UD. Berusaha dan UD. Kabela baik itu dari kecepatan, kesigapan, pengetahuan, dan keramahan sudah sangat memuaskan pembeli, hanya penampilan fisik dari karyawan tersebut baik dari berpakaian dan kerapihan yang ditunjukan belum memuaskan pembeli. Sehingga usaha kacang goyang di UD. Berusaha kalah bersaing dengan UD. Kabela.

\section{Saran}

Berdasarkan penelitian yang telah dilakukan akan kesimpulan yang di-kemukakan, maka peneliti mengemukakan beberapa saran. Kiranya saran-saran ini diharapkan dapat berguna bagi pemilik usaha UD. Berusaha dan UD. Kabela untuk mem- 
perbaiki aspek yang masih kurang. Usaha kacang goyang di UD. Berusaha dan UD. Kabela mampu memberikan kepuasan kepada pembeli sehingga disarankan kepada pengusaha kacang goyang untuk mempertahankan dan meningkatkan produksi kacang goyang mereka sehingga usaha kacang goyang dapat lebih dikembangkan dan lebih bisa bersaing. Adapun hal yang harus diperhatikan oleh UD. Berusaha dan UD. Kabela yaitu dari segi tempat dengan memperluas tempat parkir, serta tempat pemasaranya harus lebih dekat dengan pusat Kota Kotamobagu sehingga mempermudah pembeli menemukan tempat usaha tersebut. Dari segi Pelayanan, kiranya karyawaan boleh lebih memperhatikan kerapihan baik dari hal berbusana dan penampilan fisik sehingga mampu memikat para pembeli untuk membeli produk tersebut. Kemudian kepada lembaga pemerintah agar lebih memperhatikan dalam pengembangan usaha kacang goyang yang merupakan industri andalan di Sulawesi Utara sehingga diharapkan Kota Kotamobagu menjadi salah satu daerah yang mampu menyediakan kuliner khas Sulawesi Utara tersebut.

\section{DAFTAR PUSTAKA}

AAK, 1990. Budidaya Tanaman Padi. Aksi Agraris Kanisius, Yayasan Kanisius

Anonymous, 2015. Metode Importance Performance Analysis (IPA). https://ariyoso.wordpress.com/2009/12 /15/konsep-importance-performanceanalysis.

Assauri, Sofyan. 2011. Manajemen Pemasaran Dasar, Konsep, dan Strategi. Rajawali Pers. Jakarta.

Cunliffe, L Ann. 2008. Organization Theory. SAGE Publications Ltd. Esterhuizen, Dirk. J, V. Royen and Luc D' Haese. 2008. An Evaluation of The Competitivness Sector in South Africa. Advanced in Competitiveness Research.
Jones, R .Gareth. 1995. Strategic Management: An Integrated Approach. Mishawaka. USA.

Lubis, Hari. S.B. dan Martani Husaini. 2009. Teori Organisasi (Suatu Pendekatan Makro). Pusat Antar Universitas Ilmu-ilmu Sosial Universitas Indonesia. Jakarta.

Porter, M.E. (1990,1998). The Competitive Advantage of Nations. London. Macmillan.

Post Manado, 2011. Kacang Goyang Kotamobagu Andalan Masyarakat Totabuan. Manado

Salaman, Graeme dan David.Asch. 2003. Strategy and Capability, Sustaining Organizational Change . Blackwell Publishing.

Simatupang, P. 1991. The Conception of Domestic Resource Cost and Net Economic Benefit for Comparative Adventage Analysis, Agribusiness Division Working Paper No. 2/91, Centre For Agro-Socioeconomic Research. Bogor.

Sudaryanto, T dan P. Simatupang.1993. Arah Pengembangan Agribisnis : Suatu Catatan Kerangka Analisis Dalam Prosiding erspektif Pengembangan Agribisnis di Indonesia. Pusat Penelitian Sosial Ekonomi Pertanian. Bogor.

Volberda, W. Henk. And Tom Elfring. 2001. Rethinking Strategy. Sage Publications Ltd 6 Bonhill Street London. Inggris.

Waard, de Erik. 2010. Engaging Environmental Turbulence, Organizational Determinants for Repetitive Quick and Adequate Responses. Erasmus Research Institute of Management (ERIM). Erasmus University Rotterdam, Belanda. 